\title{
GROSS ALPHA AND GROSS BETA ACTIVITY LEVELS OF HOLOCENE SEDIMENTS BETWEEN ŞARKOY AND MUREFTE (TEKIRDAĞ)
}

\author{
Melike Önce $^{\mathrm{a}^{*}}$ (D), Nursel Kam ${ }^{\mathrm{b}}$ \\ ${ }^{a}$ Namık Kemal University, Çorlu Engineering Faculty, Environmental Engineering Departmant, \\ Çorlu, Tekirdăg, Turkey, monce@nku.edu.tr (*corresponding author) \\ ${ }^{b}$ Yuzuncu Yll University, Faculty of Arts and Sciences, Departmant. of Chemistry Van, TURKEY, \\ nursellkam@gmail.com
}

\begin{abstract}
Background and anthropogenic ionizing radiations are main sources of environmental radioactivity exposing human beings. Background radiation occurs as a result of cosmogenic and terrestrial radiation, while anthropogenic origins are man-made radiation. In this context, gross alpha and beta activity of sea sediment samples collected at 7 different stations in the research region (Şarköy and Mürefte) were analyzed using the low-background counter (Berthold, LB 770 10- channel $\alpha-\beta$ low-level counter). Also, the relationship between the abundance of radioactive isotopes and alpha and beta activity were discussed in this paper. As a result, the average gross alpha and beta activity was determined as 218.18 $\pm 14.9 \mathrm{~Bq} \mathrm{~kg}^{-1}$ and $579.00 \pm 23.9 \mathrm{~Bq} \mathrm{~kg}^{-1}$, respectively. Maximum gross alpha value in investigation area $301 \pm 15.9 \mathrm{~Bq} \mathrm{~kg}^{-1}$ (Şarköy Port), and the lowest value is $989 \pm 16.5 \mathrm{~Bq} \mathrm{~kg}^{-1}$ (Şarköy Port). When these values were compared with Bosna River results, both gross alpha and gross beta values were found to be high $[3,4]$. The main reason why gross alpha and beta concentrations are generally high is that the fertilizers used in agriculture contain uranium, thorium and their degradation products and natural ${ }^{40} \mathrm{~K}$.
\end{abstract}

Keywords: Gross alpha, gross beta, Marmara Sea, sediment, radioactivity

\section{Introduction}

Environmental pollution has been increasing in the last century in parallel with the increase in the population and industrial products. Increased waste pollutes the receiving environment and threatens human and environmental health. Most of these wastes are composed of pollutants that do not decompose in nature. One of these impurities is radioactive pollution. Radioactive pollution is artificial and naturally divided into two varieties. Artificial radioactive pollution is 
caused by industrial organizations, nuclear tests, and the use of nuclear weapons. While radioactive pollution caused by industrial organizations affects the water and land ecosystem, nuclear experiments and the use of nuclear weapons affect the atmosphere and harm living organisms. Natural radioactive pollution, on the other hand, is caused by radioactive elements (Radionuclides) in the structure of rocks in the soil, and particles coming from the dissolution of rocks in water. This pollution is called background radioactivity. Recently, increasing levels of environmental ionizing radiation pollution are directly related to industrialization such as the use of fossil fuels, the phosphate industry, and false and excessive fertilizers [1]. The radioactive elements are found in magmatic rocks, in phosphate rocks, in sedimentary masses such as clay and shale, and in granitic rocks in high amounts. Sedimentary rocks such as sandgravel, sandstone, and limestones with crack are found in small quantities [2, 3].

One of the most commonly used methods for determining environmental radiation is gross alpha and gross beta measurements, which are the result of quick access and low cost [4]. Determination of radioactivity in sediment samples provide information on the level of sea water radioactivity the sediment is receiving.

Numerous studies have been conducted in the past years on the identification of environmental radioactivity and the monitoring of pollution using heavy metals and radioactivity in marine environments $[5,6,7,8,9,10,11,12]$.

In this study, gross alpha and beta activity of sea sediment samples collected from 7 different stations in the Western Marmara Sea (current marine sediments) analyzed and environmental radioactivity concentration values were determined.

\section{Materials and methods}

Samples were taken from seven different locations between Mürefte and Şarköy. The bathymetry of the study area varies between $20.00 \mathrm{~m}$ and $35.00 \mathrm{~m}$ in core samples. The sampling stations between Şarköy and Mürefte (Tekirdağ) in Western Marmara Sea which is at the west part of Turkey (Figure 1). Sediment samples were immediately taken in a nylon bags and protected from atmospheric moisture. Later, the samples were taken to the laboratory, where they were removed from the nylon bags and dried in room temperature. 


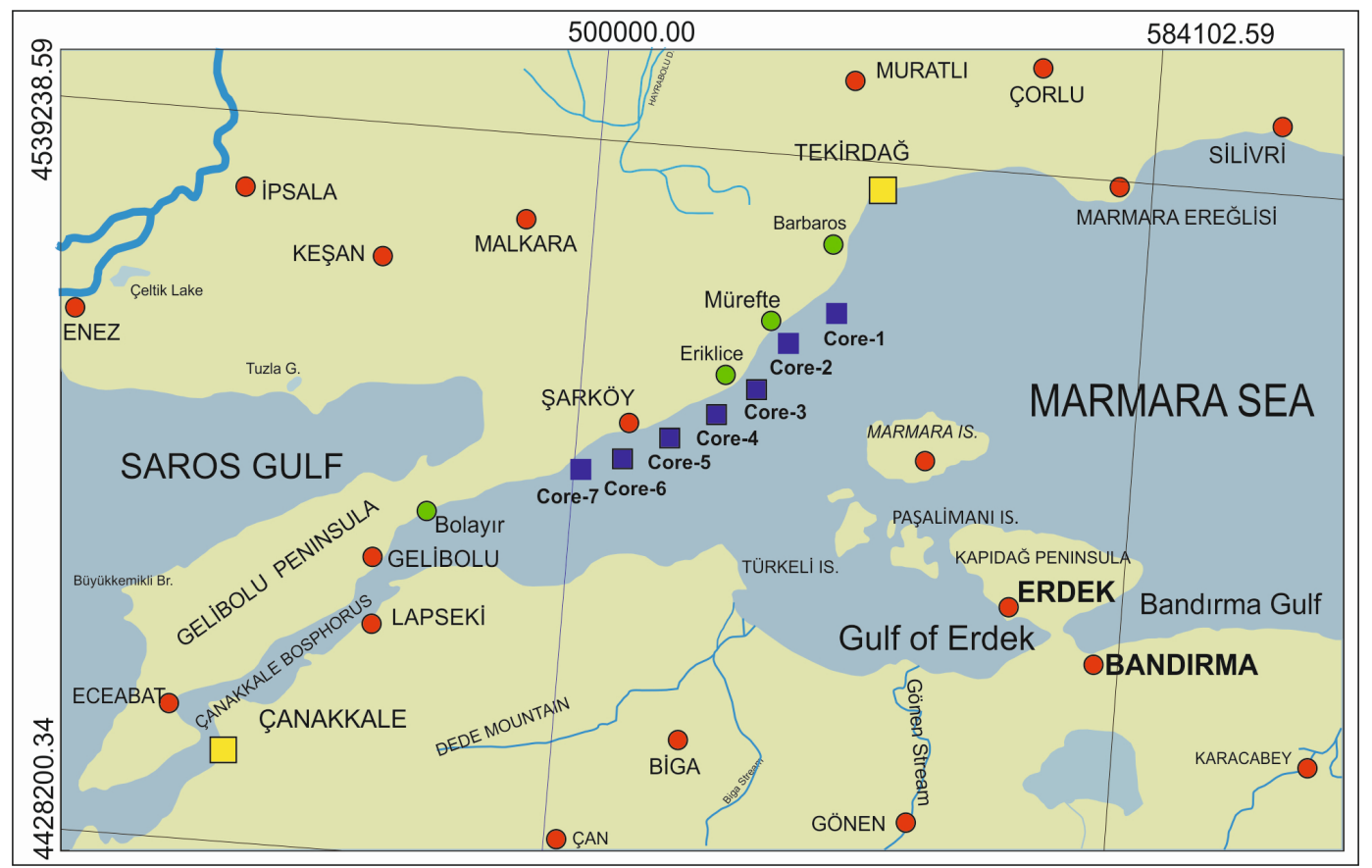

Figure 1. Location map of investigation area and samples locations

The dried sediments were ground in granite vessels and sieved with a stainless steel sieve to remove the portion that came to the size of the powder. Approximately $100 \mathrm{mg}$ of each sample was weighed on a precision scale and placed in empty aluminum vessel. Distilled pure water has been used to homogeneously distribute the samples in the vessel. The specimens were dried for 2 hours at $105^{\circ} \mathrm{C}$, then left in the desiccator to return to room temperature without drawing any moisture. Then, the prepared samples were homogenized with distilled water and placed in the oven. This process is important to determine the amount of residue. If the amount of the residue is more than $400 \mathrm{mg}$, the self-absorption effect of the alpha particles increases. In this way, fewer particles will reach the detector, causing the results to be erroneous [13]. Finally, the gross alpha and gross beta activity densities of all samples were made using two low-level LLB 770-PC 10-channel alpha-beta counting systems in two cycles of 500 minutes each.

Low level counting system is commonly used for measuring environmental samples with low natural radiation. Its calibration has been carried out with standard solutions, which contained known activities of ${ }^{241} \mathrm{Am}$ for alphas and ${ }^{90} \mathrm{Sr}$ for betas which are similar to the sample geometry [14].

\section{Results and discussion}

The study area is geologically located in the southwestern part of the Thrace Basin. In the study area, there are various lithological units of various ages and species from Middle-Upper Eocene to the Present. In the study area where basement formations are observed around Mount Ganos, the youngest formations are seen in the river beds and in the coastal area where current waves are present [23]. At the same time, this area is under the influence of the Ganos (Saroz Gaziköy) Fault in the western extension of the NAF (North Anatolian Fault) [22]. Mount Ganos, located to the south of the Ergene Basin, and its surrounding area consist of Upper Cretaceous Ophiolitic Melange (Yeniköy complex). Eocene and Miocene sequence were deposited on this foundation. The base of the Eocene sequence is the Gaziköy Formation, which is deposited in 
a deep sea environment and contains sandstone, siltstone and silicified tuff series. Uranium and thorium, which are radioactive elements, are present in higher rates in igneous rocks. Here, it is seen that volcanic movements carry the radioactive elements in the lower layer to the upper levels [24]. The contents of uranium and thorium in the earth decrease as they descend from the shell to the mantle. In addition, the presence of radioactive elements in the medium increases with the amount of silica. While granites give high uranium and thorium values, silica poor rocks give uranium values less than $0.01 \mathrm{ppm}$. Thorium content is higher in acidic environments. Potassium activity is around $0.31 \mathrm{~Bq} / \mathrm{g}$ in basalt type rocks, $0.1 \%$ in limestones and more than $4 \%$ in some granites [24]. The gross alpha and gross beta concentration of the obtained sediments are given in Table 1 and the position of the sample stations are given in Figure 1.

Table 1. Gross alpha and beta activity concentration of sediments collected from Western Marmara Sea

\begin{tabular}{lccccc}
\hline $\begin{array}{l}\text { Sample } \\
\text { Station }\end{array}$ & Gross Alpha (Bq/kg) & Gross Beta (Bq/kg) & $\begin{array}{c}\text { Sensitivity } \\
\text { Values }\end{array}$ & \multicolumn{2}{c}{$\begin{array}{c}\text { Geographic Position } \\
\text { (WGS-84) }\end{array}$} \\
\hline Core-1 & $183,20 \pm 36$ & & & Y & X \\
Core-2 & $197,166 \pm 10$ & 483,22 & \pm 41 & 519262.84 & 4500461.32 \\
Core-3 & $271,67 \pm 34$ & 139,35 & \pm 39 & 522223.40 & 4502687.90 \\
Core-4 & $164,270 \pm 41$ & 141,47 & \pm 14 & 516028.22 & 4498243.12 \\
Core-5 & $301,251 \pm 30$ & 989,47 & \pm 98 & 509303.89 & 4495098.90 \\
Core-6 & $243,64 \pm 24$ & 945,52 & \pm 94 & 509050.72 & 4495186.23 \\
Core-7 & $169,67 \pm 17$ & 862,62 & \pm 84 & 509836.72 & 4495154.21 \\
\hline
\end{tabular}

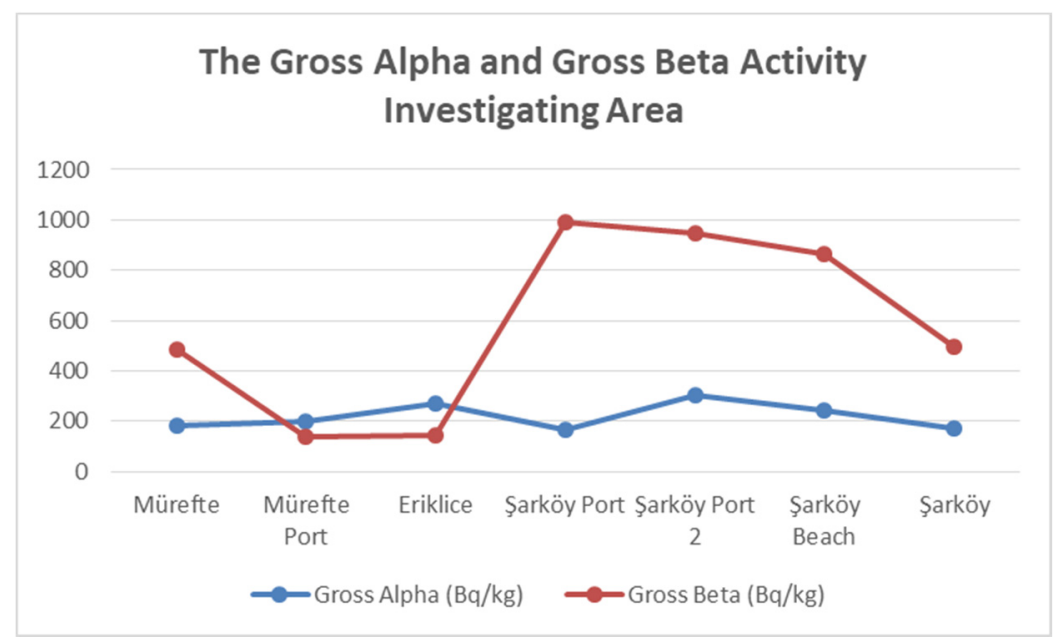

Figure 2. The gross alpha and gross beta activity concentration of sediment specimens in the Western Marmara Sea

According to the analysis results, gross beta values were found higher than gross alpha values at all locations except Mürefte Port and Eriklice. As a result, the average gross alpha and beta activity was determined as $218.18 \pm 14.9 \mathrm{~Bq} \mathrm{~kg}^{-1}$ and $579.00 \pm 23.9 \mathrm{~Bq} \mathrm{~kg}^{-1}$, respectively. Maximum gross alpha value in investigation area $301 \pm 15.9 \mathrm{~Bq} \mathrm{~kg}^{-1}$ (Şarköy Port), and maximum gross beta value is $989 \pm 16.5 \mathrm{~Bq} \mathrm{~kg}^{-1}$ (Şarköy Port). Since there is no regulatory 
standard for sediment radiological pollutants, the results obtained in this study are compared with those in other areas in Table 2 and gross alpha and gross beta activity concentration of sediment samples shown in Figure 2.

The main reason why gross alpha and beta concentrations are generally high is that the fertilizers used in agriculture contain uranium, thorium and their degradation products and natural ${ }^{40} \mathrm{~K}$. Natural radionuclides in the structure of fertilizers spread to nature as a result of excessive and unconscious use of fertilizers. These radionuclides that emit into nature threaten the environment and human health by making alpha and beta radiation.

Table 2. Gross alpha and gross beta activity concentration values compared to similar studies $[15,16,6,17]$.

\begin{tabular}{|c|c|c|c|}
\hline Stations & Gross $\alpha(\mathrm{Bq} / \mathrm{kg})$ & Gross $\beta(\mathrm{Bq} / \mathrm{kg})$ & References \\
\hline Western Marmara, Turkey & $\begin{array}{l}\text { 32,23-608,41 } \\
\text { (mean: 218) }\end{array}$ & $\begin{array}{l}\text { 38,38-1320,14 } \\
\text { (mean: 579) }\end{array}$ & Present study \\
\hline Los Alamos, New Mexico & 55,5 & 55,5 & {$[15]$} \\
\hline Bosna River, Bosnia & $\begin{array}{l}\text { 215-610 } \\
\text { (mean: 460,7) }\end{array}$ & $\begin{array}{l}495-628 \\
\text { (mean: } 539,1 \text { ) }\end{array}$ & {$[16]$} \\
\hline Bendimahi River (May), Turkey & $\begin{array}{l}782-4596 \\
\text { (mean: 2000) }\end{array}$ & $\begin{array}{l}482-10372 \\
\text { (mean: 4635) }\end{array}$ & [6] \\
\hline Sir Dam Pond (May), Turkey & $\begin{array}{l}34,8-229 \\
\text { (mean: 101) }\end{array}$ & $\begin{array}{l}\text { 144,1-419,3 } \\
\text { (mean: } 234,3 \text { ) }\end{array}$ & {$[17]$} \\
\hline
\end{tabular}

According to Table 2, the gross alpha concentration of the study is higher than Los Alamos, Bosna River, Bosnia and Sir Dam Pond. The gross beta concentration of the West Marmara is considerably lower than the Bendimahi River and is higher than other places. According to the locations where the samples are taken, there are differences in the analysis results. Core samples have it is fine-grained, sandy-silty clayey composition, because they have been taken from areas, where higher then $30 \mathrm{~m}$ depth. Concentrations of radionuclides vary depending on sediment particle size, mineral composition, local pollution and organic matter content [18]. In this study the results generally have high values compared to similar studies which are generally referred to. For this reason, ${ }^{40} \mathrm{~K}$ is the most abundant natural radioisotope in the earth's crust and soluble in abundant amounts in seawater [19].

The areas where Tekirdag's shores, Ergene River and the Gonen River's Marmara Sea are located are the most polluted areas. The reason for this is thought to be industry and ship waste. Another important reason why the gross alpha and beta concentrations are generally high is that the fertilizers are used in agriculture that contain uranium, thorium and their decomposition products and natural ${ }^{40} \mathrm{~K}[20]$.

This study shows that fertilizer and agricultural pesticide residues from the soil carried by rains in the areas where agricultural activities are concentrated cause radioactive pollution [21]. Another contribution to gross beta results is the Chernobyl nuclear reactor accident and nuclear weapons trials. Nuclear nuclei of ${ }^{137} \mathrm{Cs},{ }^{90} \mathrm{Sr},{ }^{131} \mathrm{I},{ }^{132} \mathrm{Te}$ and ${ }^{239} \mathrm{Pu}$ are spread from the nuclear reactor accident and nuclear weapons tests. Especially ${ }^{137} \mathrm{Cs}$ (half-life 30 years) and ${ }^{90} \mathrm{Sr}$ (halflife 29, 12 years) radionuclides are quite long half-lives. For this, background levels should be determined for the individual radionuclides that may create the potential pollution cause of the regions. 


\section{Conclusion}

The main purpose of this study is to determine the natural radioactivity of the region by examining the gross alpha and gross beta concentrations of sediment samples from the Western Marmara Sea. As a result, beta activity has been found to be significantly higher than alpha activity at all locations. Natural radioactivity depends directly on the regional geology, weather conditions and physicochemical variability of the water. The fact that the agricultural activities of the study area is high and is in the leading region of the country in terms of population and industry, strongly influences radioactive pollution.

\section{References}

[1] Topcuoğlu, S., Ergue, H. A., Belivermis, M., Kilic, O., "Monitoring of radionuclide concentrations in marine algae, mussel and sediment samples from the Turkish marine environment during the period of 2001-2009”. J. Black Sea/Mediterranean Environment $16(2010)$ : 285-293.

[2] Kumru, M. N., Aydin, B., Bakac, M., "Determination of natural radioactivity (Radium) in the Aegean Sea from Gediz River", Ecology Environment Magazine 10 (2002) : 2225.

[3] Karaman, E.S., "Determination of gross alpha and gross beta radioactivity levels of different Turkish marble species" İstanbul Technical University, Energy İnstitute, Master Thesis (2003).

[4] Bunz, K., Kracke,W., "Cumulative deposition of ${ }^{137} \mathrm{Cs},{ }^{238} \mathrm{Pu},{ }^{239+240} \mathrm{Pu}$ and ${ }^{241} \mathrm{Am}$ from global fallout in soils from forest, grassland and arable land in Bavaria (FRG)”, Journal of Environmental Radioactivity 8 (1988) : 1-14.

[5] Kam, E., Yümün Z.Ü., Kurt, D., “ Gross Alpha and Gross Beta Activity Concentrations in Sediments in Gulf of Izmir (Eastern Aegean Sea, Turkey)". Journal of Turkish Chemical Society, Section A: Chemistry. (2017) : 4.3.

[6] Zorer Ö., S., Ceylan H., Doğru M., "Gross alpha and beta radioactivity concentration in water, soil and sediment of the Bendimahi River and Van Lake (Turkey)”, Enviromental Monitoring and Assessment 148 (2009) : 39-46.

[7] Malanca, A., Repetti, M., Macedo, H.R., "Gross alpha-and beta- activities in surface and ground water of Rio Grande do Norte, Brazil”, Applied Radiation and Isotopes 49.7. (1998) : 893-898.

[8] Jobbagy, V., Kavasi, N., Somlai, J., Dombovari, P., Gyöngyösi, C., Kovacs, T., "Gross alpha and beta activity concentrations in spring waters in Balaton Upland, Hungary", Radiation Measurement (2011).

[9] Yümün, Z.Ü., Kam, E., "Effects of Radionuclides on the recent from the clastic sediments of the Çanakkale Strait - Turkey", Journal of African Earth Sciences. 131 (2017) : 179182.

[10] Kapdan, E., Taskin, H., Kam, E., Osmanoglu, A. E., Karahan, G., Bozkurt A. “A study of environmental radioactivity measurements for Cankiri, Turkey", Radiation Protection Dosimetry. (2011) : 1-7. 
[11] Kam E., Yümün Z.Ü., Açıkgöz G., Bayrak K., "Concentrations of enviromental radioactivity in sediment cores from Kulakçayırı Lake", Journal of Turkish Chemical Society, Section A: Chemistry 5 (3) (2018) : 1371-1374.

[12] Taskin, H., "Identification and mapping of fundraising of Kirklareli Province in terms of human health and environmental pollution", Master's thesis, Marmara University, Health Sciences Institute, Public Health Department, İstanbul (2006).

[13] Currie, L.A., "Limits for qualitative detection and quantitative determination". application to radiochemistry", Analytical Chemistry 40 (1968) : 586-93.

[14] Pentreath, R.J., "Alpha-emitting nuclides in the marine environment", Nuclear Instruments and Methods in Physics Research. (1984): 493-501.

[15] Wallova, G., Kulichova, Z., Rajczykova, E., Makovinska, J., "Survey of radioactivity along the Bosna River", J Radiation Nucl. Chem. Hungary 307 (2016) : 247-252.

[16] Çam, H., Dogru, M., Kucukonder, A., Karatepe, S., "Seasonally gross alpha and beta activity concentration in surface water and sediments in Sir Dam Pond", Kerntechnik. 78 (2013) : 431-436.

[17] Papaefthymiou, H., Papatheodorou, G., Moustakli, A., Christodoulou, D., Geraga, M., "Natural radionuclides and 137-Cs distributions and their relationship with sedimentological processes in Patras Harbour, Greece", Journal of Environmental Radioactivity 94 (2007) : 55-74.

[18] Peterson, J., MacDonell, M., Haroun, L., Monette, F., "Radiological and chemical facts sheets to support health risk analyses for contaminated areas", Argonne National Laboratory Environmental Science Division (2007).

[19] National Council on Radiation Protection and Measurements, "Radiation exposure of the U.S. population from consumer products and miscellaneous sources", NCRP report no. 95, Washington DC. (1987).

[20] Kam, E., Önce, M., "Pollution potential of heavy metals in the current sea sediments between Bandirma (Balikesir) and Lapseki (Canakkale) in the Marmara Sea”, Journal of Engineering Technology and Applied Science 1 (2016) : 141-148.

[21] Damla, N., Çevik, U., Karahan, G., Kobya, A.I., "Gross alpha and beta activities in tap waters in Eastern Black Sea region of Turkey", Chemosphere 62(6) (2006) : 957-960.

[22] Yaltırak, C., "Tectonic history of Ganos Fault System", Turkey's oil geology of journal. 8 (1) (1996) : 137-156.

[23] Okay, A., Yurtsever, A., "Metamorphic rock units of the Strandja Massif and Cretaceous rock units after metamorphism. Thrace Region Lithostratigraphy Units", General Directorate of Mineral Research and Exploration, Stratigraphy Committee Lithostratigraphy Units Series-2 (2006) : 1-41, Ankara.

[24] Erberk, E., "Thermal Structure of the Southwest Anatolia and Correlation with THE Aegean Hellenic Arc", Suleyman Demirel University Graduate School of Natural and Applied Sciences Department of Geophysical Engineering Ph.D. Thesis 110 (2018) Isparta. 